\title{
Ecological Design Strategies and Theory for Urban Parks in Seoul, 1990s-Present
}

\author{
Myeong-Jun Lee $\mathbb{D}$
}

Citation: Lee, M.-J. Ecological Design Strategies and Theory for Urban Parks in Seoul, 1990s-Present. Land 2021, 10, 1163. https: / / doi.org/ 10.3390/land10111163

Academic Editor:

Thomas Panagopoulos

Received: 31 August 2021

Accepted: 28 October 2021

Published: 30 October 2021

Publisher's Note: MDPI stays neutral with regard to jurisdictional claims in published maps and institutional affiliations.

Copyright: (C) 2021 by the author. Licensee MDPI, Basel, Switzerland. This article is an open access article distributed under the terms and conditions of the Creative Commons Attribution (CC BY) license (https:/ / creativecommons.org/licenses/by/ $4.0 /)$.
Department of Landscape Architecture, Hankyong National University, Anseong 17579, Korea; june2@hknu.ac.kr; Tel.: +82-31-670-5214

\begin{abstract}
This study explores the characteristics of and changes in Korean landscape architects' attitudes toward ecological design strategies and theories over the last three decades. Methodologically, this study includes a literature review and incorporates data from case studies and site visits. It discusses Seoul-specific contexts regarding environmental conditions, urban morphology, administrative agency, and design theory and practice. It redefines ecological parks, expanding their scope using physical and non-physical ecological processes. Considering this redefinition, this study categorizes the five main attitudes of contemporary Korean landscape architects towards ecological design: providing wildlife habitat, constructing aesthetic experiences, the phasing strategy, developing environmental learning programs, and designers' metaphoric expression. Through these attitudes, this study chronologically explores gradual and constant changes in design strategies and the discourse on ecological design. Specifically, in the 1990s, landscape architects emphasized the representation of ecosystems by constructing wildlife habitats. In the early 2000s, ecological parks were artistically designed as urban parks by reusing post-industrial landscapes. Around the 2010s, landscape architects developed resilient and adaptive design strategies to flexibly respond to uncertain changes in natural and urban ecological circumstances. Since the 2010s, landscape architects have continually expanded the scope of ecology to cover physical, non-physical, urban, and social infrastructures, including public transportation, as well as political, social, and cultural structures and virtual and augmented landscapes. This study can contribute to the field literature while adding a valuable overview of the understudied Korean context.
\end{abstract}

Keywords: Korean landscape architecture; ecological design; landscape design strategy; landscape design theory; adaptive design; post-industrial landscape

\section{Introduction \\ 1.1. Background}

Since the mid-1980s, the discourse on ecological parks has been evolving regarding the field of Korean landscape architecture [1-4]. Moreover, various ecological design strategies from the discourse have been explored and developed in Seoul over the last three decades. The theory and design of ecological parks have been discussed as part of the discourse on environmentalism. Concerns regarding environmentalism appeared in the mid-twentieth century in Europe and North America [4]. Subsequently, environmentalism has strongly influenced Korean landscape architecture since around the 1990s [1,4]. Urban parks have provided various educational and cultural programs for environmental experiences, including wildlife habitat observation and commentary programs. Simultaneously, novel design strategies to actively utilize the medium of nature have been continually explored by Korean landscape architects. Further, ecological parks are thought to epitomize the professional identity of landscape architecture, incorporating artistic and scientific activities [5-7]. As many scholars of Western and Korean landscape architecture have stated, the profession has been developed by opposing but sometimes cooperative groups, such as "environmentalists" oriented towards scientific research and "artists" pursuing creative design approaches [5-9]. In bridging the profound divide between science and art, landscape 
architects have used various ecological design solutions. This is because ecological park design requires both scientific analysis of the ecological process and artistic imagination for creative design ideation.

Most scholars in the profession have approached ecological park design in terms of aspects related to scientific instrumentality, programs for visitors, and design aesthetics. The first approach focuses on how well ecological processes are developed and managed. Specifically, these studies have explored effective and efficient ways to create and restore habitats for various wildlife species and to manage and monitor such ecological systems [10-15]. The second central approach to ecological parks entails the exploration of various forms of park visitor programs using the natural resources of an ecological park. These studies have analyzed visitor satisfaction levels and the specific characteristics and effects of various activities, including observational, experiential, educational, and cultural programs pertaining to the ecological systems of the parks, resulting in novel alternatives having been proposed $[16,17]$. Both groups of studies favor quantitative analysis over qualitative perspectives. The third approach, which has been followed in a relatively smaller group of studies, examines unique aesthetic experiences and specific design strategies of ecological parks. These studies have treated ecological design as a vehicle for the construction of novel aesthetic experiences, contrary to the idealized pastoral scenes epitomized by Frederick Law Olmsted's Central Park, which has been the dominant and conventional model of the urban park since the mid-to-late nineteenth century [6,18-20].

Korean ecological designs and theory have rarely been discussed in English research. Although Korean scholars have explored Korean projects related to science, human recreation, and design aesthetics as discussed above, they have not adequately highlighted the discourse and design strategies related to Korean ecological parks and their continual changes over the last three decades. A recent study in English explored Korean landscape design strategies and theory to transform post-industrial landscapes into urban parks [21]. It followed a chronological pattern and briefly addressed several Korean urban park projects using ecological processes. Focusing on the Korean context, the study explained the recent Korean history of landscape architecture, which has been highly influenced by Western design trends and theory [21]. However, it barely examined the discourse on the ecological design strategies and their changes. Indeed, to fully understand Korean design practice and the theory of landscape architecture during the last three decades, the theme of ecological design requires focus and scrutiny.

\subsection{Research Objective and Methodology}

Focusing on the Korean context, this study explores various design strategies and theories regarding ecological parks and chronologically examines the changes in them over the last three decades. It first discusses Seoul-specific conditions related to the ecological design of urban parks regarding the natural environment, urban morphology, administrative policy perspective, theory, and design practice of landscape architecture. It then briefly provides an expanded scope for ecological parks, which includes not only a legal definition but also a redefined notion of it, including various design activities for urban parks related to ecology. Thereafter, this study categorizes five main Korean attitudes towards ecological design within the redefined scope of ecological parks: wildlife habitats, ecological design aesthetics, phasing strategy, environmental education, and metaphoric expression.

In the sections that follow, this study discusses changes in ecological design strategies and theory over the last three decades. Specifically, it addresses the ecological design of urban parks in metropolitan Seoul (Figure 1), because as the capital of South Korea it is the site of many early Korean ecological parks and significant works that are well known in the field of Korean and international landscape architecture. Further, many international design competitions involving ecological design strategies are currently held in Seoul. This study chronologically scrutinizes noteworthy built, unbuilt, and ongoing projects 
and the discourse on ecological design since the early 1990s, thereby discussing specific understandings and ecology design strategies and the changes in them.

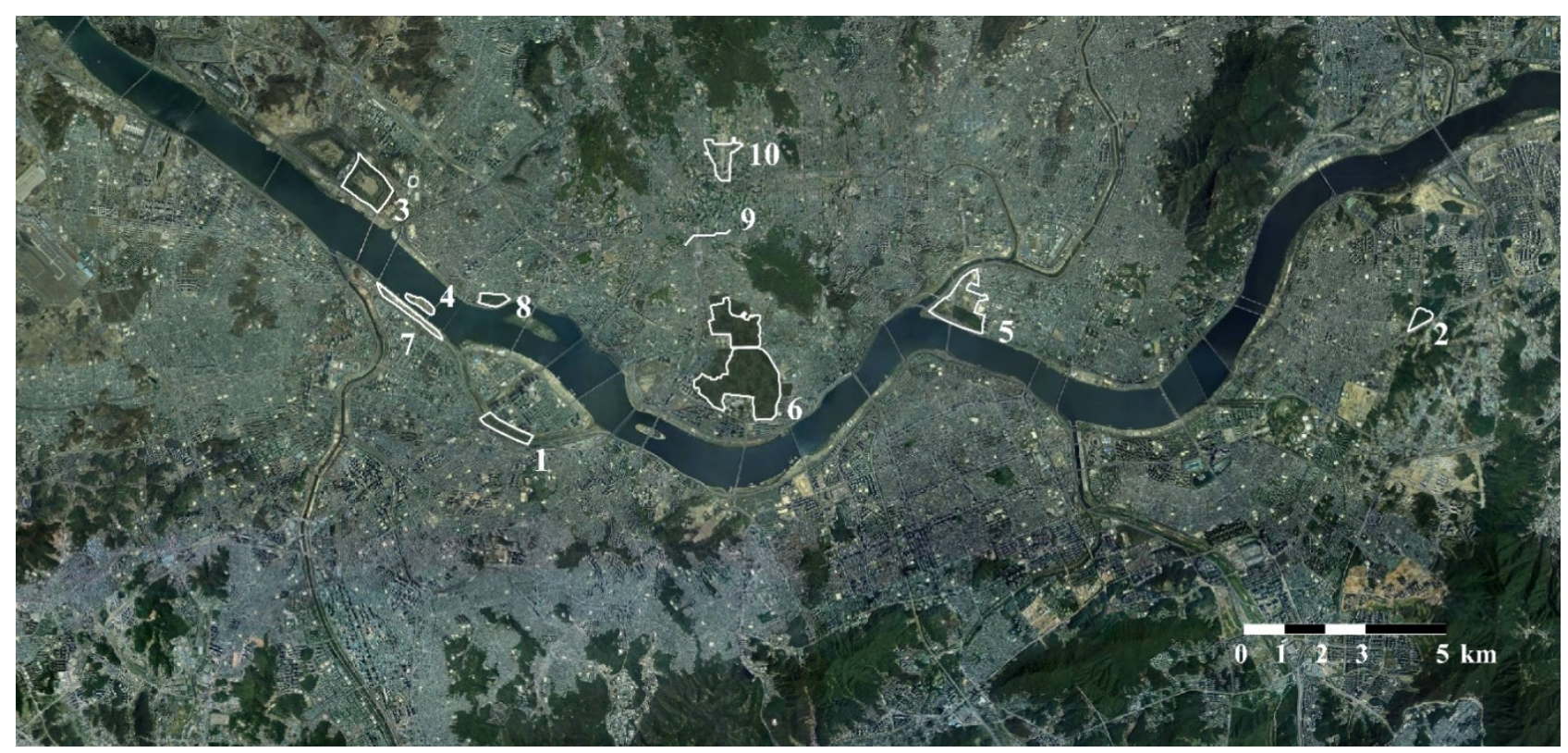

Figure 1. Distribution of case study sites and related conditions in Seoul: (1) Saetgang Ecological Park; (2) Gildong Ecological Park; (3) Haneul Park; (4) Seonyudo Park; (5) Seoul Forest Park; (6) Yongsan Park; (7) Mud Infrastructure; (8) Thermal City; (9) Seoullo; (10) Gwanghwamun Square. Source: Author's drawing based on a digital map from the National Geographic Information Institute of Korea.

Methodologically, this study consists of a literature review and incorporates data from case studies and site visits. First, we thoroughly examine the existing literature and knowledge in the field. Specifically, scholarly works related to ecological design published in the Journal of the Korean Institute of Landscape Architecture (the prominent bimonthly journal of the field) and in Landscape Architecture Korea (the only monthly magazine for Korean landscape architecture) are scrutinized. Second, ten ecological parks frequently mentioned in the above literature are selected for the case study. In addition, further literature is examined, including official reports, books, and proposals for design competitions related to the ecological design for the selected parks. Third, site visits to built projects (seven out of the ten selected parks) are conducted to carefully examine how designers' visions are expressed in the construction process and how these projects have been used and managed. These site visits facilitate the collection of visual materials that support the discussions in this study. Through these processes, this study further explores changes in Korean landscape architects' thinking, the theory of ecological design, and its specific strategies.

\section{Ecological Parks of Seoul}

\subsection{Aspects of Seoul}

Seoul's ecological parks have been highly influenced by various conditions in the city, including its natural environment and urban morphology and the Seoul Metropolitan Government's (SMG) administrative direction, design theory, and practice of landscape architecture (Figure 1). First, regarding environmental conditions, the Korean topography consists of several mountains, meaning the terms "landscape" refers to a dynamic mountainous area [21,22]. This is contrary to the Western concept, in which landscapes are horizontal surfaces or green and urban infrastructure [21-23]. Seoul includes mountains of different sizes that are widely dispersed throughout the city; in the middle of the city is the approximately $600 \mathrm{~m}$ wide Hangang (Han River). The mountainous terrain of Seoul contrasts with the flat planes of other capital metropolitan cities, including Beijing, Tokyo, 
Washington D.C., London, Paris, and Berlin [24] (p. 35). Due to the environmental conditions of the city, the citizens' recreational activities take place in urban parks, amid the natural environment. Thus, in the design and planning of urban parks, landscape architects tend to widely utilize landscape possibilities by linking the ecological environment and the urban aspects of the sites.

Second, regarding the urban morphology, Seoul consists of different scales and forms of urban surfaces. Specifically, much of the northern area of the Han River was planned from the Joseon Dynasty, more than 600 years; therefore, it consists of many irregular-sized parcels of land. However, unlike the northern region (old downtown), much of the southern area of the river comprises relatively regular grids of streets and avenues, which were planned and constructed according to the land adjustment policy of Gangnam. This policy has impacted the commercial, business, and residential districts of apartment complexes in the southern area of the Han River since around the early 1970s [24] (p. 56). These various types of urban surfaces and structures permeate and intertwine with the unique natural environment of the city. In other words, the complex and distinctive conditions have provided landscape architects the opportunity to develop novel design strategies.

Third, regarding the administrative agency, the SMG, which serves as the local government of Korea, has been promoting experimentation with new forms of urban parks. For example, the earliest discourse on ecological parks in Korea related to the conversion of Seoul's Nanjido landfill into urban parks in the early 1990s. Officially, the earliest ecological parks in Korea, such as Saetgang and Gildong ecological parks, were constructed in Seoul in the late 1990s. Moreover, the SMG has held many domestic and international design competitions and research projects, leading to the development of novel and innovative approaches to ecological design. The SMG manages the specialist division, the Department of Green City, which systematically conducts many design and management projects related to urban greening, based on its slogan "Seoul full of forests and gardens" [21].

Fourth, along with design theory and practice, Korean landscape architects have voluntarily and positively embraced Western landscape architectural discourse and design trends. In Korea, landscape architecture was initially established as an occupation around the 1970s by embracing the professional identity of American landscape architecture [8]. As a former study illustrated, scholars and designers who studied and worked abroad introduced the current theoretical perspectives and design trends of Western landscape architecture into Korea from the 1990s onwards [21]. The Korean discourse and practice of ecological design have been highly influenced by the contemporary Western trends in landscape architecture since the early 1990s. In other words, the recent history of Korean ecological parks epitomizes the characteristics of acceptance and change in East Asian landscape architecture, influenced by the West. Nonetheless, as some Korean scholars have argued, the Western discourse relating to ecological design needs to be adequately revised to address Korean contexts [21,22].

\subsection{Expanded Scope of Ecological Parks}

To fully understand the various ways to deal with ecological design in Korean urban park design, this study needs to redefine the current scope of ecological parks. This study examines two specific methods to redefine ecological design, namely the "legal definition" and "meaning in the theory and practice." First, this study examines the legal definition of the term "ecological park" in the "Act on Urban Parks, Green Areas" of the Korean legislation, as well as the relevant ordinance of the Seoul Metropolitan Government. Second, it examines the scholarly literature and design proposals to identify the meaning of an "ecological park."

First, the term "ecological park" in Korea is a legal term in the relevant laws related to urban park establishment and management. One type of urban park is a "theme park", which has a specific purpose. An ecological park is a type of theme park that creates habitats for wildlife species to enhance biodiversity and provides citizens with daily human recreation, relaxation, and ecological learning [25]. In accordance with the "Act on Urban 
Parks, Green Areas" in the Korean legislation, the term "theme park" includes "historical parks," "cultural parks", "waterside parks", "cemetery parks", "sports parks", "urban agricultural parks", and "disaster prevention parks" [26]. Further, the SMG prescribed the relevant ordinance that added "ecological parks" and "amusement parks" in 2007 and "street parks" in 2010 within the category of "theme park" [27]. However, the legal definition of an ecological park has limited functions and is meant for administrative procedures, as well-known urban parks, including Saetgang and Gildong ecological parks, do not fall within the legal category. In other words, a discrepancy between the two meanings has been discovered.

Thus, instead of employing the limited legal understanding, this study provides an alternate, broader definition of ecological parks. First, the definition "ecological park" includes various types of urban parks that incorporate physical ecological processes. Specifically, ecological parks create wildlife habitats by preserving, regenerating, and representing the ecosystem; they often involve bioremediation, which consists of transforming polluted and contaminated landscapes, including post-industrial sites and brown fields. Thus, this scope includes most ecological parks that fall within the legal definition. Second, the redefined scope of ecological parks refers to urban parks that exploit non-physical ecological aspects. Although they rarely create physical ecological areas such as wildlife habitats, the designed landscapes sometimes provide ecological activities, including online or offline educational and cultural visitor programs related to the ecological design of the sites. Third, built, unbuilt, and ongoing urban parks incorporating design strategies that treat the ecological process as a metaphorical expression are included in the renewed scope of ecological parks. Considering the alternative redefinition, this study carefully examines the existing literature and knowledge of the profession, thereby categorizing current Korean landscape architects' main attitudes towards ecological design for urban parks.

\section{Attitudes toward Ecological Design}

\subsection{Ecology and Wildlife Habitats}

Ecology involves the study of places of habitation for wildlife species by many researchers involved in Korean landscape architecture. The history of the attitude of the largest group of landscape architects can be traced back to the mid-twentieth century in Ian McHarg's environmental planning manifesto, Design with Nature [28]. For this group, ecology describes scientific systems that need to be monitored, controlled, and predicted using technological solutions $[10,13,14,29]$. The ecological deterministic tradition has influenced design approaches to ecological parks. The advocates of scientific environmentalism focus on preserving or restoring the existing or former natural conditions of sites, which are often actively linked to their surrounding environments, including wildlife habitats, when designing ecological parks. To achieve representation of natural environments, such landscape architects deploy various eco-technologies to predict, monitor, and manage quantifiable ecological processes. As this group pursues successional processes in wildlife ecosystems, they avoid human interventions in ways that focus on limited wildlife observation.

\subsection{Constructing Aesthetic Experiences}

Another group of Korean landscape architects treats ecological design as a creative vehicle for the construction of aesthetic and environmental experiences. Unlike the advocates of scientific environmentalism, many in this group believe that ecological design is an artistic activity. They do not reduce ecological design to technological methods; rather, they employ the ecological processes as active tools for creating an aesthetic identity for the site [18-21]. This approach has been highly influenced by the seminal theory and practice of landscape urbanism led by James Corner and Charles Waldheim [30], as well as the sustaining beauty manifesto codified by Elizabeth Meyer $[5,6]$. The theory and design practice have been embraced by Korean scholars and designers since around the 2000s [21]. For example, design projects for the transformation of post-industrial landscapes into 
urban parks have involved design strategies that combine industrial ruins and ecological processes, thereby creating unique aesthetic experiences that invoke the sublime and melancholic sensibilities.

\subsection{Phasing Strategy}

The third attitude towards ecological design involves the phasing strategy for sites. Korean landscape architects often employ open-ended and adaptive processes to flexibly respond to the changing natural, urban, political, economic, social, and cultural desires regarding the designed landscapes [31-33]. This performative strategy has evolved from the two attitudes discussed in Sections 3.1 and 3.2. Specifically, similar to followers of the first group, those who follow the phasing strategy try to predict future natural or urban ecological performance and rationally plan suitable uses for the sites. Further, as with the second attitude, this strategy utilizes ecological and hydrological processes to construct unique aesthetic experiences of beautiful landforms either gradually or dramatically. To visualize the phasing process, landscape architects use a well-known mapping technique devised by James Corner. The phasing visualization process is a hybridized form of a masterplan and diagrams, allowing formative and creative operations [29,34].

While the first attitude tends to consider ecosystems as closed and stable structures of traditional environmental determinism, the phasing strategy reflects a resilient outlook of ecosystems as being open, complex, and unpredictable [35] (p. 36). Moreover, while the second attitude tends to be applied for relatively small sites, the phasing strategy can be effectively used for the design and planning of large-scale sites. It was formulated based on the discourse and design practice related to large parks [36], following the landscape urbanism approach.

\subsection{Environmental Education}

In designing urban parks, Korean landscape architects have used ecological design as an effective method for environmental education. This group has devised various programs that provide opportunities to monitor and experience the physical wildlife habitat of ecological parks [16,17]. In Korea, due to the gradual reductions in working hours and changes in the perceptions of human recreation and leisure, urban parks have been used as spaces for recreational activities since around 2000. Interestingly, since the late 1990s, when urban park programs emerged, ecological activities have consistently been a part of urban park programs [37]. Specifically, landscape architects have created informative ecological programs for environmental learning for professional and volunteer commentators, field tours with limited or direct experiences relating to wildlife species, and online content using virtual or augmented realities related to the metaverse, which have emerged due to the coronavirus disease 2019 (COVID-19) pandemic. More importantly, as Elizabeth Meyer has stated, through such an environmental somatic experience of the designed landscapes, visitors can adopt environmental values and ethics [6]. In this sense, this educational approach to ecological design resonates with the second attitude, whereby ecological design is understood as the construction of the aesthetic experience of designed landscapes.

\subsection{Metaphorical Expression}

Korean landscape architects often use ecology as an expressive medium to unfold design strategies. Many people from this group create metaphorical expressions to describe their design strategies in ways that visualize the similarities between the future possibilities of the sites and the characteristics of the natural environments. Specifically, they draw descriptive and graphical analogies between the changing characteristics of the various types of urban infrastructure, including the culture, transportation, economy, and policy related to the sites and the dynamic, performative, and ever-changing characteristics of the physical ecosystem [19]. Such symbolic gestures have appeared in design diagrams and collages included in competition proposals for urban design projects. The proposals 
submitted to international competitions for Korean urban parks by international star designers epitomize the metaphoric expression of ecology. These symbolic gestures have often been criticized as "designer ecology" or "ecology as image", which superficially imitate ecological processes and are not physically operational [35,38]. However, such analogical gestures provide challenging opportunities that create a new understanding of ecology, the scope of which has been constantly expanding from natural to urban environments, including virtual landscapes such as interactive biophilic media façades.

\section{Changes in Ecological Design Strategies and Theory}

\subsection{The 1990s: Representing Ecology}

In Seoul, the ecological discourse first emerged around the 1990s, when landscape architects focused on the representation of ecology at the sites by constructing wildlife habitats. For example, in 1993, the SMG announced a plan for ecological parks that would transform Nanjido from a landfill into urban parks. The site of Nanjido had been a landfill in the Seoul metropolitan area for over fifteen years, since 1978. Environmental issues were constantly raised about the landfill being in the vicinity of the city; hence, Gimpo and Incheon were designated as the new landfills. As a result, the Nanjido landfill was closed in 1993. In the plan, the most important issue was the stabilization of the contaminated grounds. The scientific environmental analysis of the leachate treatment and cover up and the vacuuming of methane gas in the polluted area were prioritized. The SMG's basic plan to convert Nanjido into an urban park followed the research and reports of many Korean scholars in landscape architecture in the late 1980s. The pioneering studies introduced theories and knowledge of built projects in Western ecological parks, including William Curtis Ecological Park and Camley Street Natural Park in London, to Korean landscape architects [1-3]. Thereafter, after 2000, the site underwent an artistic design treatment. The actual built projects in the 1990s were Saetgang (opened in 1997) and Gildong (opened in 1999) ecological parks (Figures 2 and 3). The former is situated in Saetgang, one of the branches of Hangang, which runs through the south of Yeouido, Seoul's financial district. The park created various habitats for wildlife species using existing wetlands, thereby functioning as a riparian corridor between Hangang and Saetgang. The latter was built on land that was previously supposed to be used for agriculture; different types of ecological grounds, including wetlands, forests, lakes, and meadows, were created, thereby connecting the zones of the park and the ecosystems of the vicinal mountains, including Iljasan and Seungsangsan. The two parks have been acclaimed as masterpieces and as contributing to a paradigm shift in landscape design by many Korean critics and designers [39].

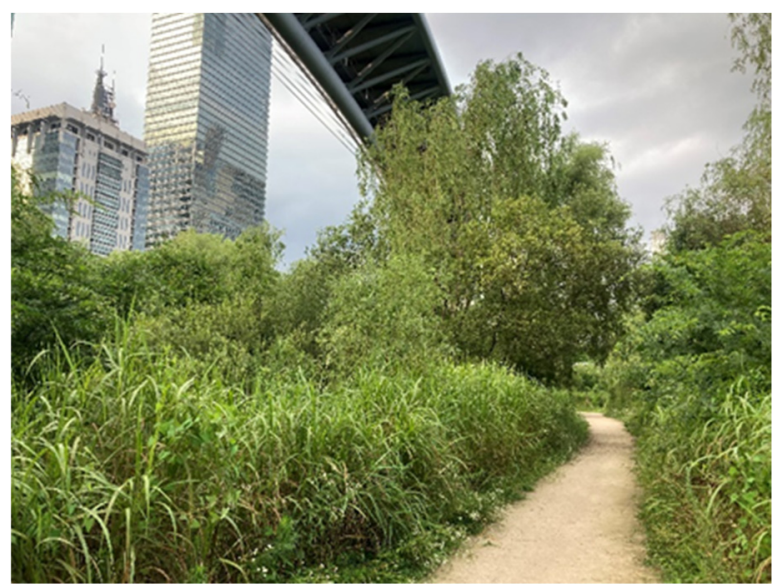

(a)

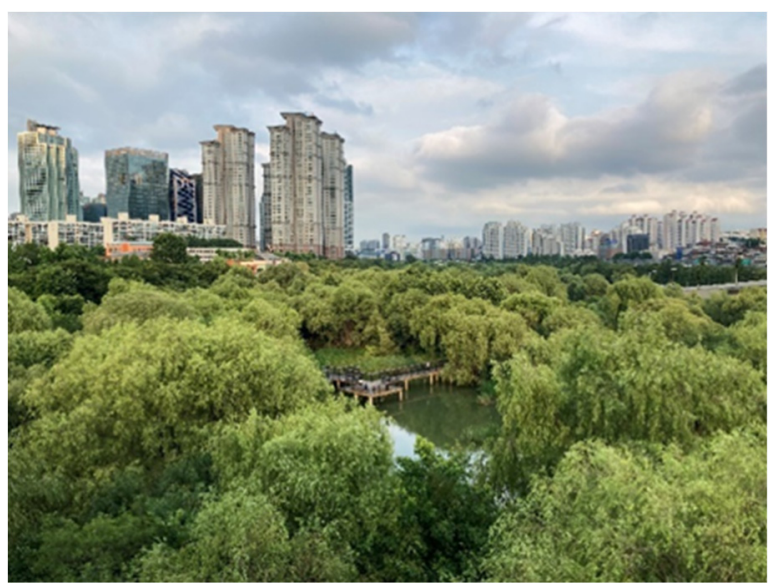

(b)

Figure 2. Saetgang ecological park: (a) pastoral landscape of the promenade; (b) a view overlooking the park. Source: Author's photographs. 


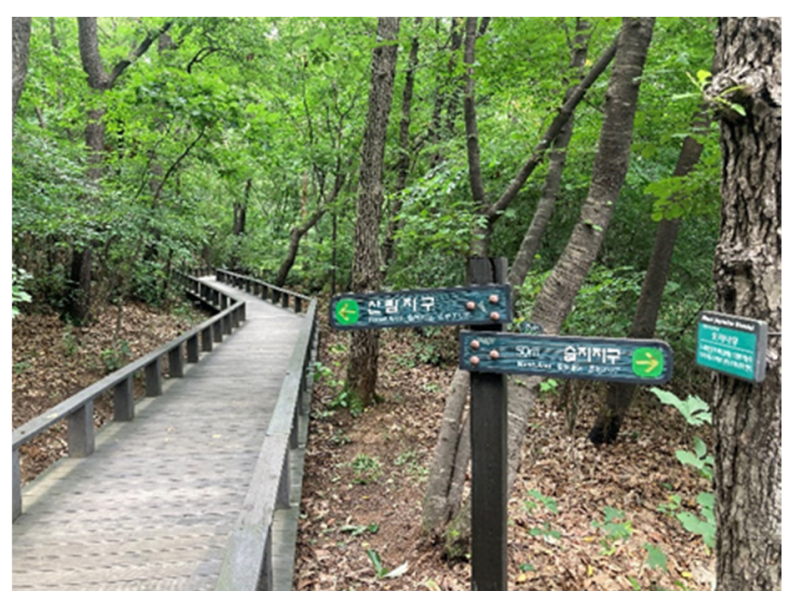

(a)

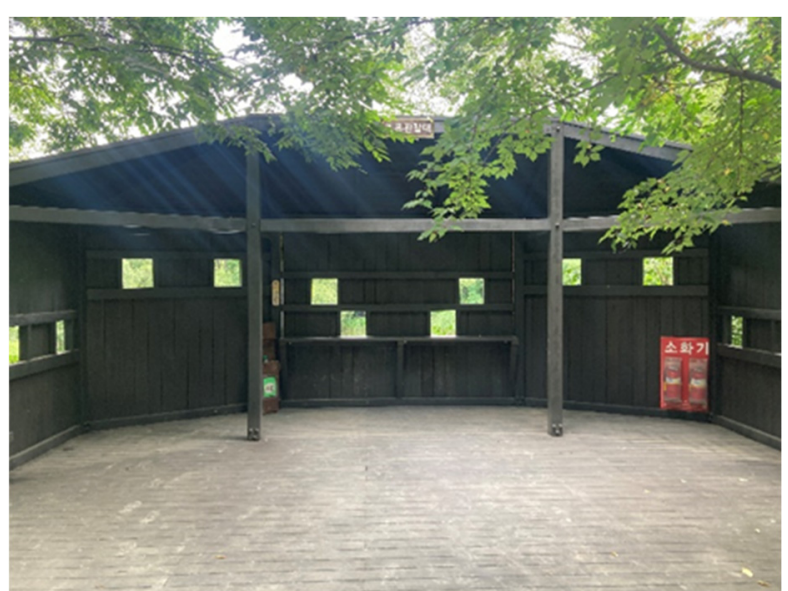

(b)

Figure 3. Gildong ecological park: (a) walking deck with a repetitive form; (b) limited observation point for birdwatching. Source: Author's photographs.

Built and unbuilt ecological design projects constructed in Seoul in the 1990s shared roughly three characteristics. First, the parks from this time were designed according to a linear model of ecological development, a conventional understanding of ecosystems that follows "a linear path of development toward a particular biologically diverse and stable climax state" [35] (p. 41). According to the environmental determinism approach of Ian McHarg, landscape architects tried to represent the untouched state of the sites $[10,40,41]$. Various construction technologies and materials used to achieve Western-type ecological restoration were emphasized and embraced by Korean landscape architects [4]. Second, the ecological scientism within urban park design led to a lack of creative design. For example, although Gildong ecological park provided different types of zones that epitomize the characteristics of ecological design to monitor wildlife habitats in the downtown area, the design touches were invisible, except for the repetitive walking and observation decks (Figure 3a). Moreover, the park has a limited capacity for visitors (30 to 40 per hour, 400 per day) to prevent human intervention in wildlife habitats. More importantly, the discourse and practice of the time followed an incorrect notion of ecological aesthetics. Specifically, the aesthetic properties of natural ecological design were equated with pastoralism, as epitomized by Olmsted's urban parks [41]. In fact, regarding aesthetic categories, the quality and roughness of untouched wilderness pertains to the "sublime", which is contrary to the "beauty" of pastoral landscapes $[20,42,43]$. The meadow landscapes used ecological parks of the time tended to tame the rough and wild characteristics of the real ecosystems (Figure 2a). Third, educational and cultural programs in ecological parks were first developed during this period. Saetgang and Gildong ecological parks had limited wildlife habitat observation programs, which were guided by professional ecological commentators. Thus, Seoul's ecological parks from the 1990s represented wildlife habitats on these sites and allowed limited human intervention, thereby epitomizing the dominant binary dualism between nature and humans (Figures $2 b$ and $3 b$ ).

\subsection{The Early 2000s: Artistic Ecological Parks}

After 2000, Seoul's ecological parks began to be artistically designed. In particular, design projects to transform post-industrial landscapes into urban parks were highly acclaimed for their excellent design qualities by Korean and international scholars and critics $[21,44,45]$. Korean landscape architects treated ecological design as the process of constructing unique aesthetic experiences beyond the representation of wildlife habitats. For example, Haneul Park (Sky Park, opened in 2002) was designed to create a wide field full of reeds atop the high landform of the Nanjido landfill discussed in Section 4.1, after the stabilizing processes undertaken in the 1990s (Figure 4). Seonyudo Park (opened in 2002, American Society of Landscape Architects Award 2004) was the first Korean ecological 
park established in a post-industrial landscape. The site previously functioned as a water purification plant for twenty years (Figure 5). Seoul Forest Park (opened in 2005), situated in Ttukseom, is a large urban park that was also established on a post-industrial site that previously functioned as a water purification plant, recreation park, and golf course (Figure 6). As a former study explained, the Korean landscape architecture of the 2000s enthusiastically embraced Western theories of landscape urbanism and various design proposals, including those for Downsview Park in Toronto (established in 2000) and Fresh Kills Landfill Park in New York (established in 2001), which highly influenced Korean design and theory in this field $[21,46,47]$.

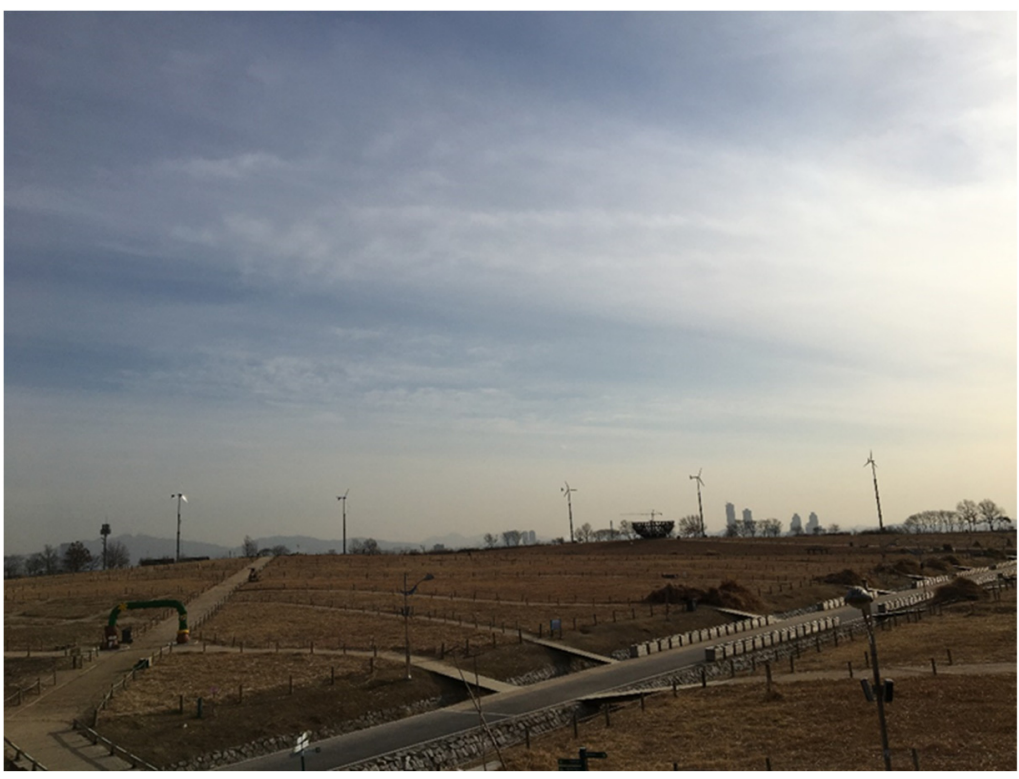

Figure 4. View overlooking Haneul Park. Source: Author's photograph.

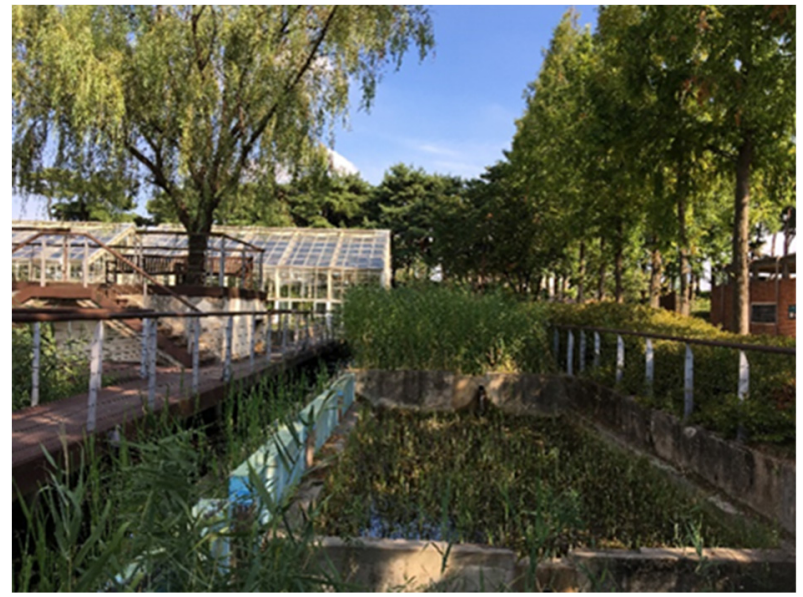

(a)

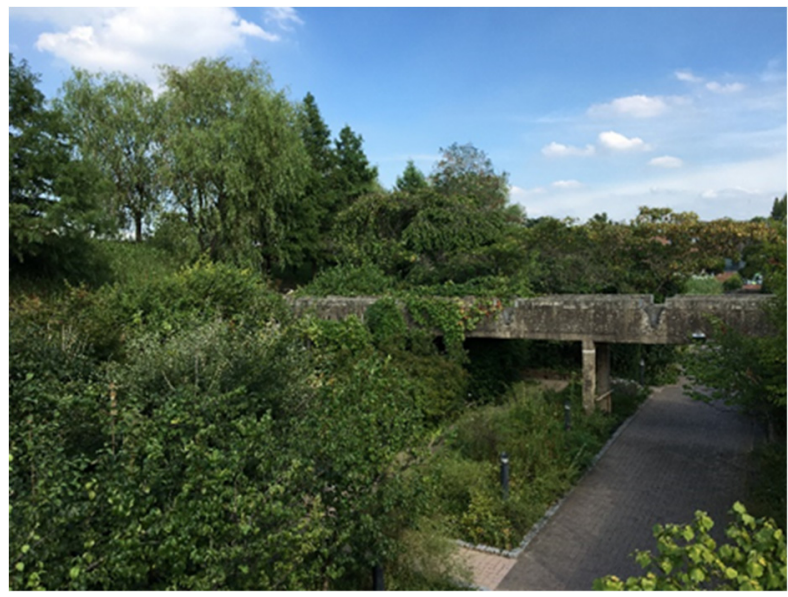

(b)

Figure 5. Seonyudo Park: (a) water purification basin; (b) transition garden. Source: Author's photographs. 


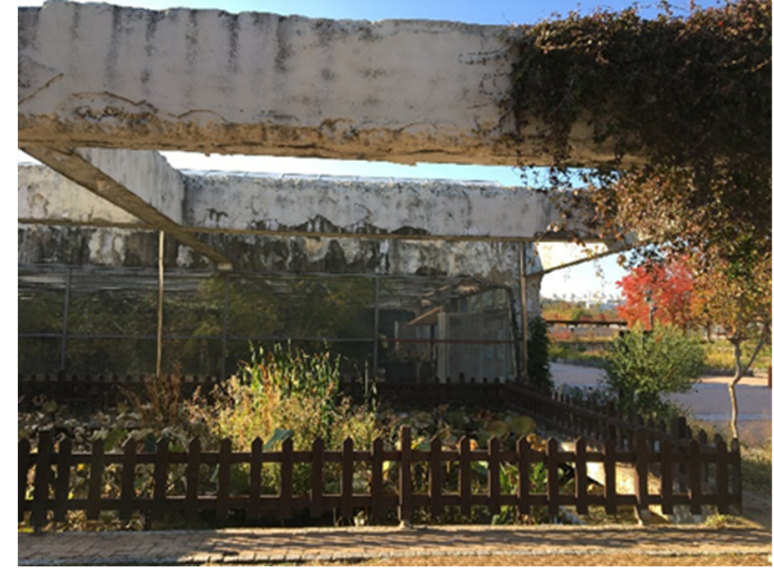

(a)

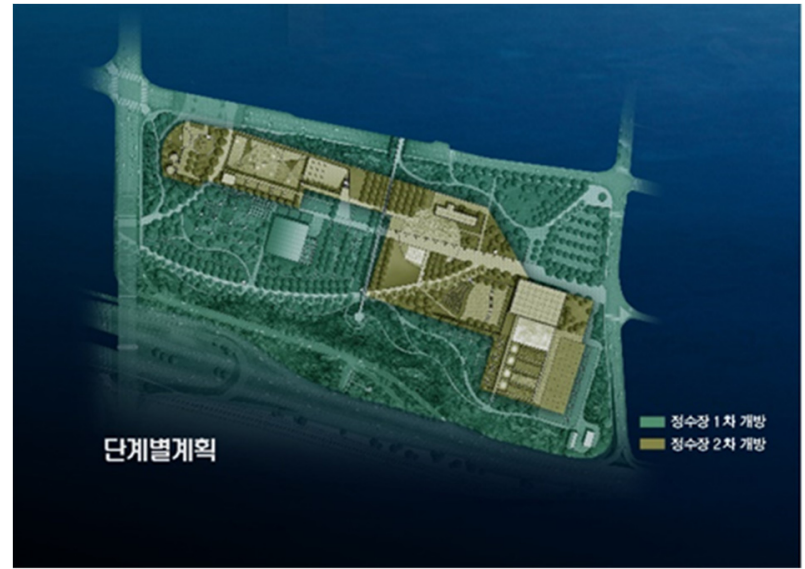

(b)

Figure 6. Seoul Forest Park: (a) butterfly garden; (b) phasing plan for the original design. Sources: (a) author's photograph; (b) Dongsimwon Landscape Design and Construction Co. et al., [48].

Korean ecological design involved three main characteristics in the 2000s. First, in designing ecological parks, landscape architects began to embrace human design interventions. The original design for Haneul Park, Seonyudo Park, and Seoul Forest Park involved creative design strategies, such as the reuse and recycling of existing architectural structures as physical containers for the ecological processes and as aesthetic objects [48-50]. In these projects, ecological was no longer perceived as relating to untouched wilderness pre-dating the human civilization, but was alternatively understood as involving performative processes that can revive industrialized areas. Second, the revised perception of ecology incorporated unique aesthetic experiences. For example, Seonyudo and Seoul Forest Parks contained novel aesthetic experiences pertaining to sublime aesthetics by juxtaposing the coexistence of rusting industrial ruins with various aquatic and wildlife plants (Figures 5 and 6a). As stated by Elizabeth Meyer, the appearance of designed landscapes and their subsequent aesthetic experience can provide environmental value and an understanding of the relationship between industrialization by humans and ecosystem health [6]. More importantly, the ecological experiences of these ecological parks were more somatic than the contemplative and passive observations associated with the early ecological parks of the 1990s. Further, Seoul Forest Park offered various types of monitoring and experiential programs developed through public-private partnerships to foster visitors' active engagement in wildlife habitats. Third, the phasing plan for Korean ecological parks emerged. The winning proposal for the Seoul Forest Park competition, which was highly influenced by design proposals for the Downsview Park competition, made use of design strategy in the flexible long-term construction process (Figure 6b). However, the phasing plan was vague in determining the development of and the opening sequence for the large sites [21].

\subsection{Around 2010s: Resilient Ecology}

Around 2010, ecological design began to reflect the emerging shift in the ecological discourse in Seoul. Specifically, urban park design and planning projects began to incorporate the paradigm change of ecological thinking from "closed, hierarchical, stable, and deterministic structures functioning according to a linear model of development" to "living systems as open, complex, self-organizing, and unpredictable" [35] (p. 36). In other words, in order to flexibly respond to uncertain and changeable natural and urban circumstances, landscape architects created resilient phasing strategies involving open-ended and adaptive processes rather than deterministic 'master' planning. In fact, the shift in the perception of the ecological process had already been reflected in design practice, such as in the Downsview Park and Fresh Kills Landfill Park competitions, before it was reflected in the theory. The subsequent theory of landscape urbanism was first introduced into 
Korean landscape architecture in 2001 [51]. It further evolved into a discourse on large parks in 2007 [36], which was translated into Korean in 2010 [52]. Further, the concept of landscape urbanism had been revised into ecological urbanism by strengthening the social and political roles of landscape designers regarding urban ecology and the third world [53-55]. The reformed versions of landscape urbanism affected Korean ecological design projects. The former is epitomized by the Yongsan Park project (General Basic Plan in 2009-2019, international design competitions in 2012), which is a long-term and ongoing plan to convert one of the US Army garrisons into a large park situated between Namsan and Hangang (Figure 7). The latter was successfully applied to Mud Infrastructure constructed in the Yanghwa section (Figure 8), in the vicinity of Seonyudo, Hangang waterfront (opened in 2011), and Thermal City (Figure 9), as well as to a proposal for the Danginri Underground Combined Heat Plant (2013) situated between the Hongik University district and Hangang.
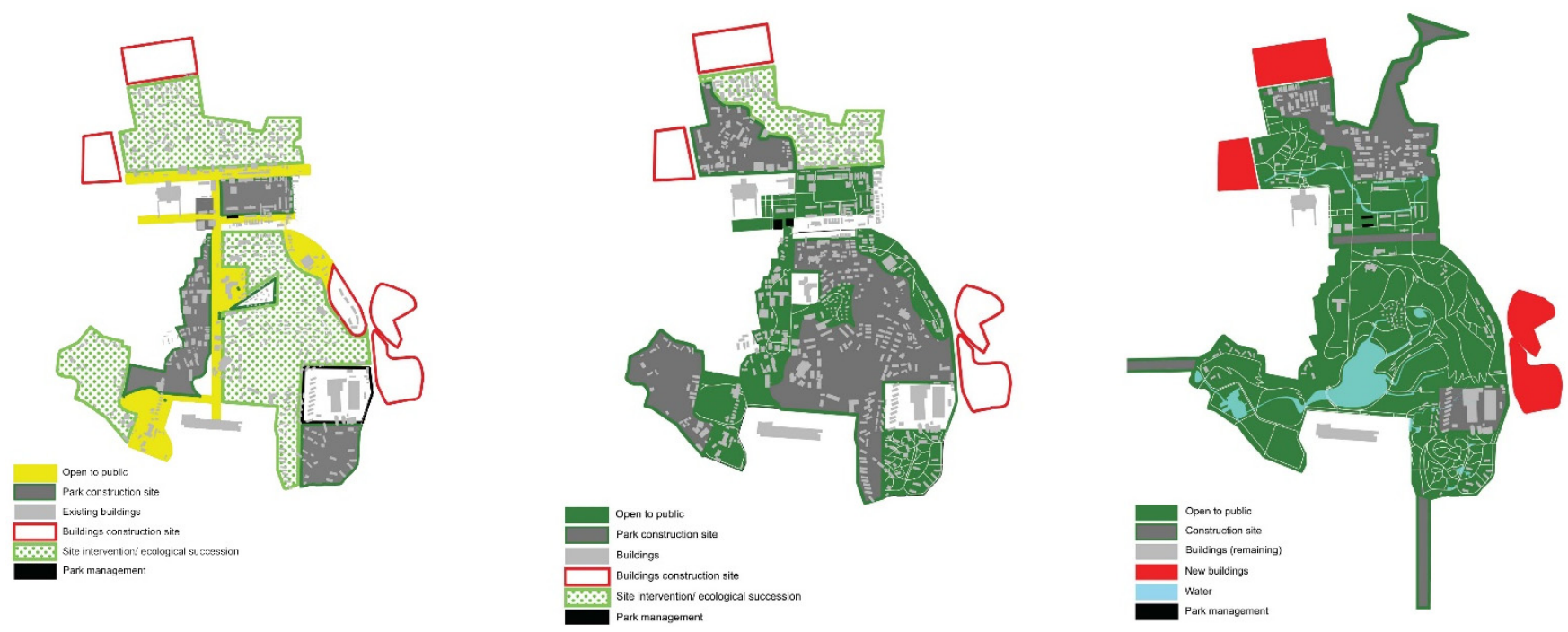

Figure 7. Phasing plan for Yongsan Park (sources: West 8 and Iroje et al., [56]).

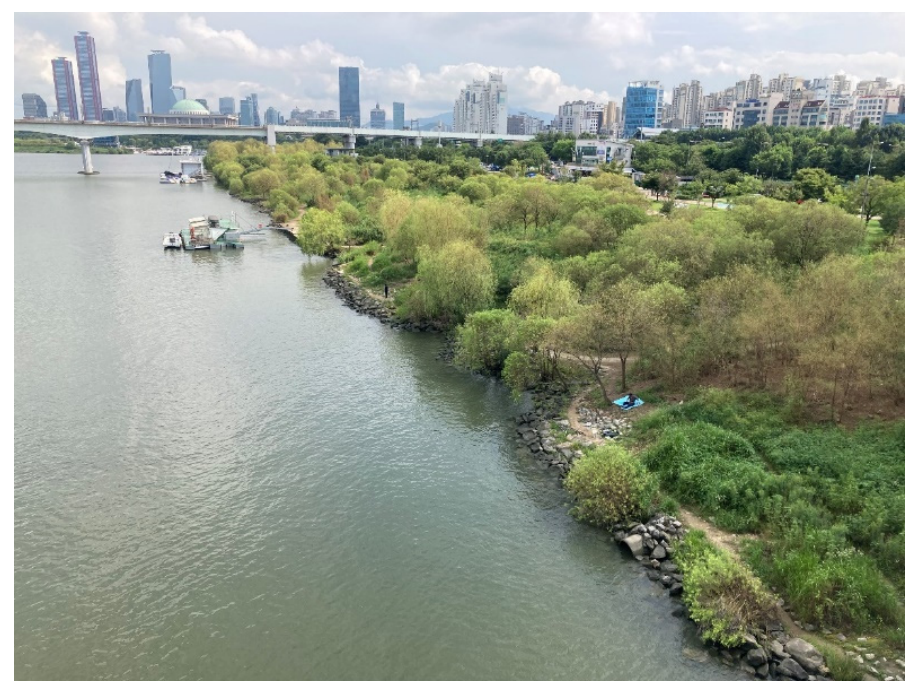

Figure 8. Bird eye's view of mud infrastructure (source: author's photograph). 


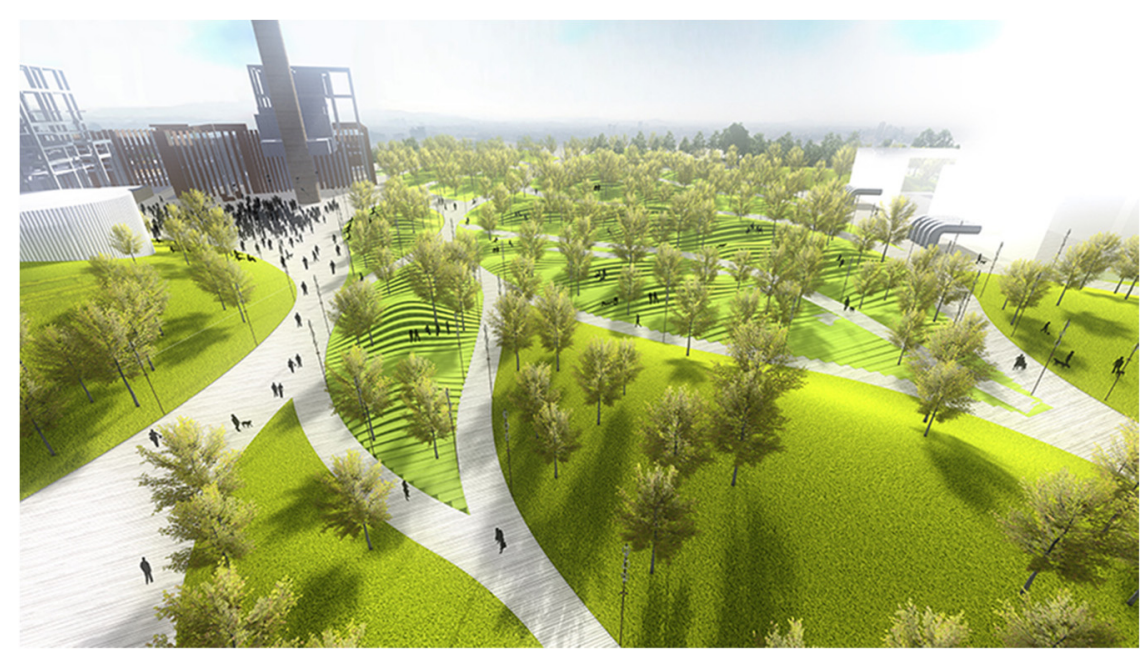

Figure 9. Bird's eye view of Thermal City (source: PARKKIM, [57]).

The significant changes in attitude toward the ecological design of the time were as follows. First, in large park design, a specific phasing strategy considering a wide range of issues of natural and urban ecology was developed. For example, the general basic plan and winning proposal in the international competition for Yonsan Park was used to create an adaptive, flexible, long-term phasing plan; an evolved version of the rough phasing strategy in the winning proposal was developed in response to various disturbances and changes, including natural, cultural, social, political, and economic issues, which were treated as ecological organisms within successional processes. The phasing strategy then became popular in Korean urban design and in the planning of large sites [31-33]. Second, the long-term phasing strategy reflected the shift in the understanding of ecology and in the discourse on resilience. The resilience of a large park, as Julia Czerniak described, is the "ability to accommodate diverse and shifting social, cultural, technological, and political desires while maintaining its identity" [58] (p. 216). The phasing of the winning proposal for Yongsan park epitomized the resilience of an urban park [59], although the specific construction process is still uncertain due to the complicated Korean political circumstances and environmental contamination of the military site (Figure 7). The resilient design of urban parks is currently treated as a significant theoretical perspective in Korean landscape architecture [60]. Third, digital modeling, fabrication, and construction technologies were used as active design tools for the various landforms performing ecological functions. Korean landscape architects have often been criticized for their lack of use of digital technology for landscape design [9]. Mud infrastructure requires 3D modeling technology to model the undulating mounds (Figure 8). Specifically, the landforms were carefully tested and then formulated using Rhino modeling, considering seasonal floods and subsequent sedimentation, which could help in creating habitats for the wildlife species in Hangang [9] (p.21), [61], [62] (pp. 23-24). Further, Thermal City (Figure 9), based on the simulation of thermal comfort indices, incorporates artistically curved heated seating, using hot water from a power station, which could control the microclimate of the site [9] (p. 21), [61], [62] (pp. 116-117).

\subsection{The Late 2010s to the Present: Extended Ecology}

More recently, Korean landscape architects have been exploring novel forms of ecology, including urban and social aspects. Whereas previous landscape architects tended to treat ecosystems as the natural environment, covering wildlife species and their habitats, recent landscape design projects in Seoul have been continuously extending the definition of ecology to physical, non-physical, urban, and social infrastructures, including public transportation, as well as political, social, and cultural structures. Moreover, the emerging discourse on smart cities has enabled landscape architects to explore various technological forms for urban design and planning, such as big data analysis, artificial intelligence, 
and eco-technologies [63]. Most recently, the conception of the metaverse, which refers to the collective virtual shared space formed by the convergence of virtual and physical spaces, has emerged in Korea; thus, the definition of a landscape now not only covers material aspects but also refers to both virtual and physical spaces. Recent competition entries for open-space design in Seoul have highlighted different creative design strategies using various forms of renewed ecological design. For example, Seoullo (opened in 2017) is a linear elevated park that reused a former highway overpass constructed in the 1970s, situated next to Seoul Station (Figure 10). Another significant project is the winning proposal for the new Gwanghwamun Square [64], which is situated in front of Gyeongbokgung, the main royal palace of the Joseon Dynasty, which has functioned as a national symbolic square since the Joseon Dynasty (Figure 11). Further, digital technologies have been used to create computational and adaptive design tools for Korean open spaces. First, using parametric technology, including Rhino3D and Grasshopper, attempts have been made to generate fluid and curvilinear surfaces of landforms and structures in Korean urban parks and gardens $[65,66]$. Second, a simulation model of thermal comfort was used to monitor and increase the adaptation and resilience of urban open-space design and planning approaches [67].

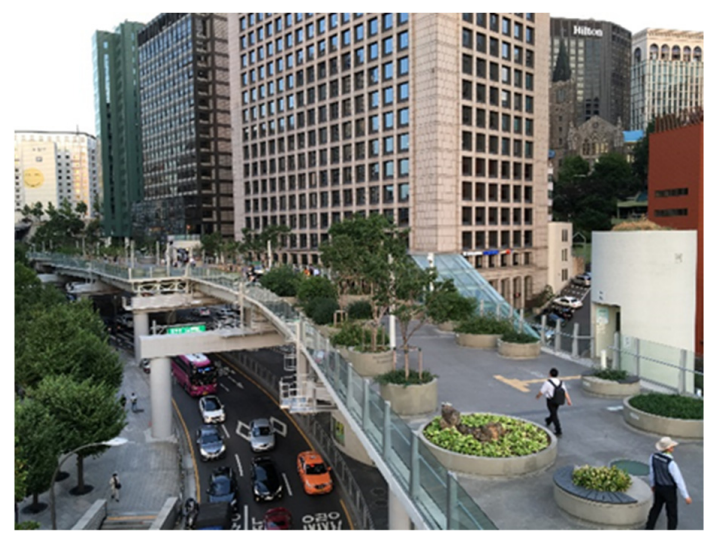

(a)

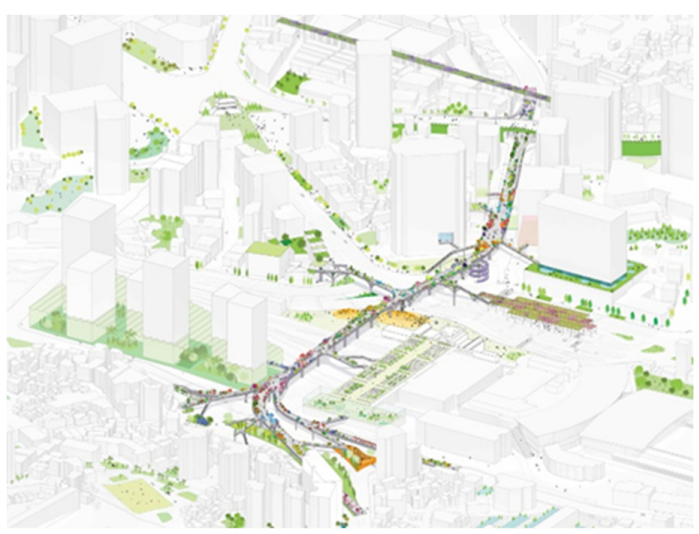

(b)

Figure 10. The Seoullo project: (a) current view; (b) Seoul Arboretum-a perspective of the original design (source: (a) author's photograph; (b) MVRDV, [68]).

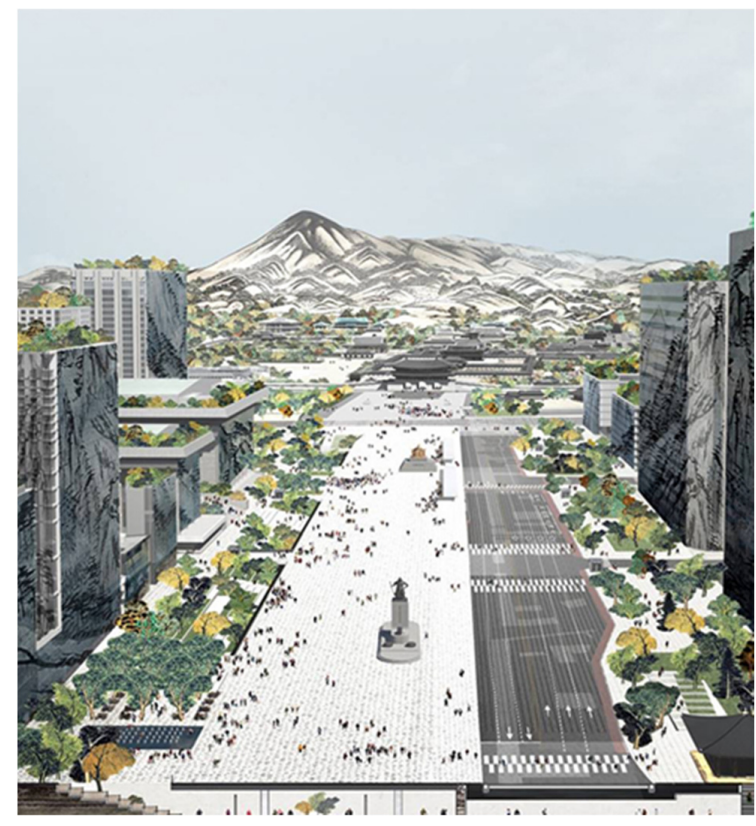

Figure 11. Bird's eye view of Gwanghwamun Square (source: CA Landscape et al., [64]). 
Recently, designers have drawn analogical expressions between ecological processes and future changes in urban infrastructure. For example, the winning entry of the Seoullo competition, Seoul Arboretum, incorporated a creative design idea that converted a former linear transportation structure into a pedestrian walkway full of trees and plants (Figure 10b). Specifically, the linear forms of the architectural structure function as ecological veins, which gradually spread everywhere across Seoul's downtown [21,68]. Second, the virtual landscape functions as a design tool to foster and embody ecological processes. The winning proposal for the Gwanghwamun Square competition, Deep Surface, incorporated a novel technological-driven ecological design approach (Figure 11). This was a symbolic gesture that connected an underground space, a square plot, and the façades of architectural structures, including the main administrative, cultural, and commercial buildings, as well as their roof gardens, involving the design of a virtual landscape inspired by traditional Korean landscape paintings on the façades of the buildings [64,69]. Third, novel forms of ecological learning using push notification services (SNSs) and mobile applications are emerging. This is a result of the limited activities taking place in urban parks due to the COVID-19 pandemic. The SMG currently offers various types of online programs that enable a virtual experience of Seoul's urban parks [25]. Specifically, the SMG uploads videos capturing wildlife species in ecological parks, often accompanied by commentators' narration, along with real-time broadcasting content to effectively communicate with citizens as virtual visitors (Figure 12). These new forms of content are used as alternative ecological learning tools for a wide range of educational institutions, including primary, secondary, and higher learning schools.

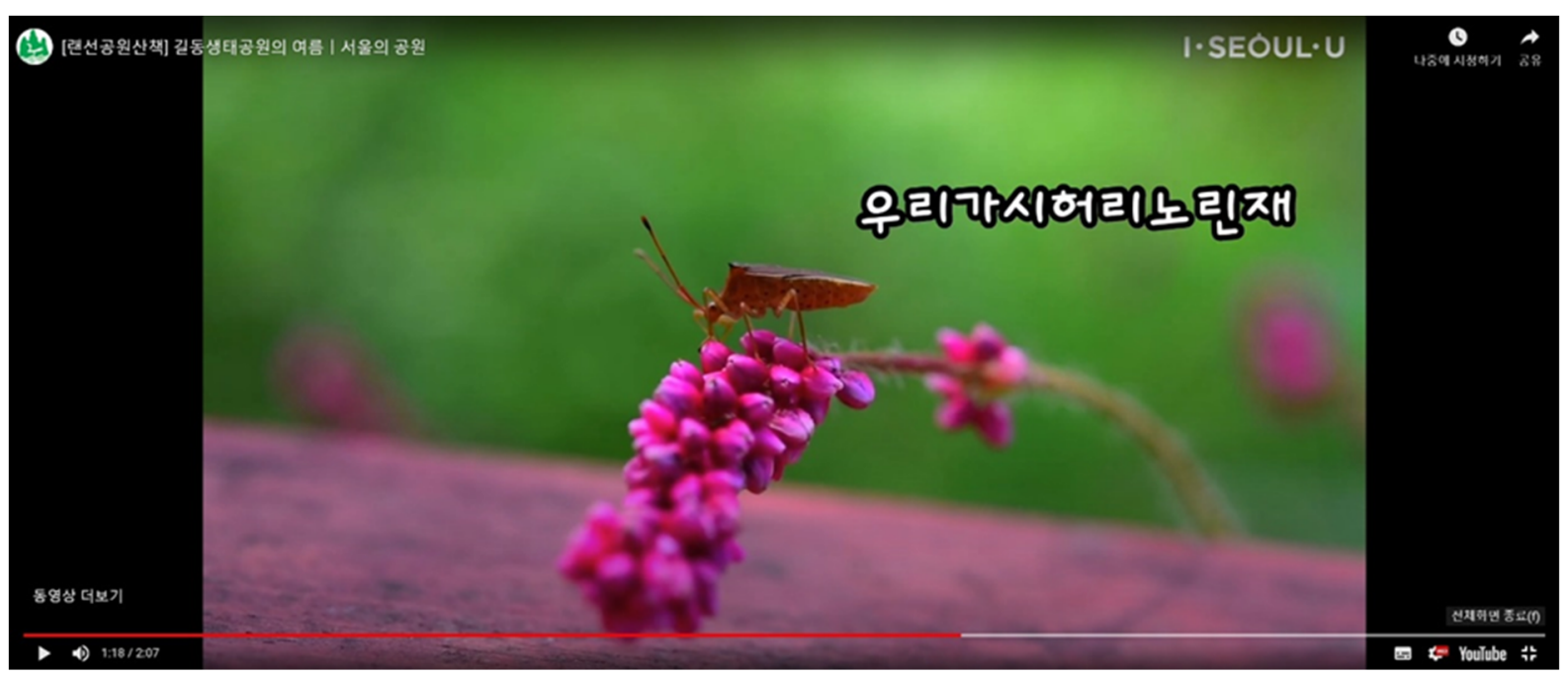

Figure 12. Online program for Gildong Ecological Park (source: Department of Green City, [25]).

\section{Discussion and Conclusions}

As this study has shown, Korean landscape architects' attitudes toward ecological design and specific design strategies and theory have been gradually changing, thereby constantly expanding their former notion of ecology since the early 1990s, when the ecological discourse and design practice first emerged. This paper first discussed Seoul-specific contexts pertaining to ecological design for urban parks. The ecological conditions and environment in Seoul, comprising a dynamic mountainous landscape, have provided opportunities for landscape architects to link the ecological environment to the urban tissues of various sites. Regarding the urban morphology, the complex intertwining of various types of urban landscapes and tissues with the natural environments in Seoul have offered opportunities to create novel design strategies for open-space designs. Further, regarding the administrative agency, the SMG have been managing the Department of 
Green City, thereby promoting many initiatives and projects related to ecological parks. Moreover, regarding design theory and practice, the Korean discourse and the practice of ecological design have been highly influenced by the contemporary Western trends in landscape architecture since the early 1990s. Instead of adhering to the limited existing legal understanding of urban parks, this study presented an alternate definition with a broader scope that refers to urban parks using physical and non-physical ecological processes, including online and offline ecological learning programs and symbolic gestures of ecological processes in the competition proposals for urban parks. Based on this redefinition, this study categorized contemporary Korean landscape architects' five main attitudes towards ecological design. Specifically, ecological design covers wildlife habitats, aesthetic experiences, phasing strategies, environmental learning programs, and designers metaphorical expression.

Chronologically, landscape architects' attitudes, strategies, and discourse on ecological design have gradually but consistently changed. In the 1990s, landscape architects focused on the representation of ecosystems at sites by constructing wildlife habitats. First, they were influenced by a conventional concept of the ecosystem that followed a linear model of development toward a particular stable climax state. Second, ecological scientism led to a lack of creative design strategy regarding ecological parks. Third, educational and cultural programs for ecological parks were developed, although they were limited to wildlife habitat observation programs.

In the early 2000s, ecological parks began to be artistically designed, with design projects converting post-industrial landscapes into urban parks. Initially, landscape architects fully embraced human design interventions in the ecological parks. Thereafter, ecological parks began to incorporate unique aesthetic experiences by juxtaposing rusting industrial ruins with wildlife plants. Subsequently, phasing plans for ecological parks emerged, although they are often vague.

Around the 2010s, landscape architects developed resilient and adaptive design strategies to flexibly respond to uncertain changes in natural and urban ecological circumstances. First, specific long-term phasing strategies considering a wide range of disturbances of natural and urban ecosystems were created. Second, the phasing strategy reflected a shift in the discourse on resilience in large park designs. Third, digital modeling, fabrication, and construction technologies were used as creative design tools for landforms to provide aesthetically beautiful spaces and functioning ecosystems.

More recently, since the 2010s, landscape architects have been continuously extending the concept of ecology to cover physical, non-physical, urban, and social infrastructures, such as public transportation, as well as political, social, and cultural structures and virtual and augmented landscapes. First, analogical expressions have been drawn between ecological processes and future changes in urban infrastructure. Second, technology-driven virtual landscapes have functioned as design tools to foster and embody virtual and actual ecological processes. Third, creative forms of ecological learning using SNS and mobile applications are developing in response to the limited activities taking place in urban parks due to the COVID-19 pandemic.

This study also has several limitations. First, the five prevalent attitudes of Korean landscape architects towards ecological design are not distinct. Rather, the different perceptions of ecological design have a certain similarities. In designing an ecological park, the various aspects, include the wildlife habitats, unique experiences, phasing strategies, ecological learning tools, and metaphorical expressions, can be merged. Moreover, the four characteristic periods from the last three decades are not distinct. The design strategies and discourse regarding ecological design have been gradually revised and have evolved over time. Second, ecological design strategies and the discourse surrounding them are often difficult to embody in actual sites. Symbolic and graphical expressions of ecological processes and even phasing plans that thoroughly consider various changing circumstances frequently fail to achieve this in a site due to sudden environmental, social, and political disturbances. In this sense, the current significant discourses and design 
strategies regarding resilient parks need to be consistently expanded. Third, given that similar projects for ecological parks have been promoted by the SMG and many local governments in Korea, the visual appearance and ecological performance of ecological parks have come to gradually be seen as clichés, although ecological design strategies, as seen in the above-mentioned design studies, have constantly evolved. Thus, Korean landscape architects need to creatively explore unique design identities for individual urban parks by continuously expanding the concept of ecology and considering Korean-specific conditions. Since the ecological design discourse originated from Western landscape architecture applied mainly to Western conditions, it is necessary to revise it to address Korean contexts. Korean ecological design will function as a tool to dissolve binary dualism constructs between science and art within this profession and will contribute to Korean landscape theory, design practice, and pedagogy.

Funding: This work received no external funding.

Conflicts of Interest: The author declares no conflict of interest.

\section{References}

1. Hyeon, J. Case studies of ecological parks in overseas: Ecological parks in the United States. Environ. Landsc. Archit. Korea 1993, $61,66-71$.

2. Jeon, Y. A Master Plan for Nanji-do Ecological Garden. Master's Thesis, Seoul National University, Seoul, Korea, 1987.

3. Oh, K. A Study on Standard for Planting Design Considering Ecological Characteristics of Natural Plants. Master's Thesis, Seoul National University, Seoul, Korea, 1986.

4. Oh, K. Ecological park: Planning and designing. Environ. Landsc. Archit. Korea 1993, 61, 48-53.

5. Meyer, E.K. The post-Earth Day conundrum: Translating environmental values into landscape design. In Environmentalism in Landscape Architecture; Conan, M., Ed.; Dumbarton Oaks Research Library and Collection: Washington, DC, USA, 2000; pp. 187-244.

6. Meyer, E.K. Sustaining beauty: The performance of appearance. A manifesto in three parts. J. Landsc. Archit. 2008, 3, 6-23. [CrossRef]

7. Pae, J. Deconstructing the dichotomy between ecology and art in contemporary landscape architecture. J. Korea Soc. Environ. Restor. Technol. 2003, 6, 48-56.

8. Lee, M.; Pae, J.; Oh, M.; Kim, M.; Son, E. The origin of landscape architecture as urbanism. In Proceedings of the Spring Academic Conference of the Korean Institute of Landscape Architecture, Seoul, Korea, 27 March 2015; pp. 33-35.

9. Lee, M. Transformation of discourse on uses of computer technology in Korean landscape architecture: Focused on Journal of the Korean Institute of Landscape Architecture and Environmental \& Landscape Architecture of Korea. J. Korean Inst. Landsc. Archit. 2020, 48, 15-24.

10. Choi, B.; Lee, K. The management plan of the Youido Satkang ecology park based on ecosystem monitoring. Korean J. Environ. Ecol. 2001, 15, 26-38.

11. Jang, B.; Sung, L.; Lee, S.; Kim, J.; Lee, S. A study on design method of water space in ecological park: Focused on ecological park in Seoul. J. Korea Inst. Ecol. Archit. Environ. 2002, 2, 49-56.

12. Jeon, S.; Cha, Y.; Choi, J. Floral changes during three years after the establishment of the Youido ecology park. J. Korean Inst. Landsc. Archit. 2000, 28, 76-86.

13. Kim, K.; Cho, D.; Cha, Y.; Hwang, K. A study on the development of planting design method for creating an ecological park: Focus on a correlation between visual preference and ecological diversity. J. Korean Inst. Landsc. Archit. 2000, $27,12-24$.

14. Lee, K.; Lee, S.; Jang, J.; An, I. Creation techniques of ecological park to consider urban forest ecosystem in Woomyeongsan urban nature park, Seoul. J. Korean Inst. Landsc. Archit. 2005, 33, 79-96.

15. Seong, K.; Lee, K.; Choi, J.; Kim, J. Problem analysis and suggestion for improved approaches to ecological planting and the establishment of urban parks: A case study of the nature ecological forest in Yeouido park, Seoul. J. Korean Inst. Landsc. Archit. 2011, 39, 91-102. [CrossRef]

16. Kim, E.; Lee, J.; Kim, H.; Chon, J. The visitors characteristics of urban ecological park: The cases of Gildong ecological park, Yeouido tributary ecological park. J. Korean Inst. Landsc. Archit. 2014, 42, 64-74. [CrossRef]

17. Sung, S.; Kim, Y. The environment interpreter's the educational effects at ecological parks: In the case of the Gil-dong ecological park. J. Korean Inst. Landsc. Archit. 2001, 28, 52-61.

18. Ahn, J. Ecology as Media in Landscape Design. Master's Thesis, Seoul National University, Seoul, Korea, 2013.

19. Corner, J. Ecology and landscape as agents of creativity. In Ecological Design and Planning; Thompson, G., Steiner, F., Eds.; John Wiley \& Sons: New York, NY, USA, 1997; pp. 81-105.

20. Lee, M.; Pae, J. An aesthetic interpretation of post-industrial parks with a perspective of the sublime. J. Korean Inst. Landsc. Archit. 2012, 40, 78-89. [CrossRef] 
21. Lee, M. Transforming post-industrial landscapes into urban parks: Design strategies and theory in Seoul, 1998-present. Habitat Int. 2019, 91, 102023. [CrossRef]

22. Zoh, K. Prospect of Korean Landscape Urbanism: Dilemma and potential. In Proceedings of the International Symposium of Korean Institute of Landscape Architecture; Landscape Urbanism: The New Paradigm of Landscape Architecture and Urbanism for Green-Led Regeneration in the 21st Century, Seoul, Korea, 22 October 2010; pp. 203-213.

23. Corner, J. Landscape Urbanism. In Landscape Urbanism: A Manual for the Machinic Landscape; Mostafavi, M., Najle, C., Eds.; AA Publications: London, UK, 2003; pp. 58-63.

24. Kim, S. Seoul Solution; Hyenamsa: Seoul, Korea, 2020.

25. Department of Green City. Available online: http://parks.seoul.go.kr/ (accessed on 20 August 2021).

26. Korea Ministry of Government Legislation. Available online: https://www.law.go.kr (accessed on 10 August 2021).

27. Seoul Metropolitan Government Ordinance. Available online: https://legal.seoul.go.kr (accessed on 10 August 2021).

28. McHarg, I. Design with Nature; The Natural History Press: New York, NY, USA, 1969.

29. Lee, M. James Corner's theory and practice of representation: Characteristics and functions of landscape architectural drawing. J. Korean Inst. Landsc. Archit. 2017, 45, 118-130.

30. Waldheim, C. (Ed.) The Landscape Urbanism Reader; Princeton Architectural Press: New York, NY, USA, 2006.

31. Kim, Y.; Jeong, W. Development of Landscape Urbanism in practice. J. Korean Inst. Landsc. Archit. 2014, 42, 1-17. [CrossRef]

32. Park, K.; Pae, J. Design strategies of large park in the international design competition for central open space in multi-functional administrative city, Korea. J. Korean Inst. Landsc. Archit. 2008, 36, 13-25.

33. So, J.; Sung, J.; Pae, J. An analysis of process-oriented design in the invited entries of international competition for the master plan of the Yongsan Park, Korea. J. Korean Inst. Landsc. Archit. 2013, 41, 11-26. [CrossRef]

34. Corner, J. The agency of mapping: Speculation, critique and invention. In Mappings; Cosgrove, D., Ed.; Reaktion Books: London, UK, 1999; pp. 213-252.

35. Lister, N.M. Sustainable large parks: Ecological design or designer ecology. In Large Parks; Czerniak, J., Hargreaves, G., Eds.; Princeton Architectural Press: New York, NY, USA, 2007; pp. 35-58.

36. Czerniak, J.; Hargreaves, G. (Eds.) Large Parks; Princeton Architectural Press: New York, NY, USA, 2007.

37. Department of Green City. Current Conditions and Ways of Development of Park Programs for Citizen's Leisure Activity: Focusing on Urban Parks of Seoul Metropolitan Government; Seoul Metropolitan Government: Seoul, Korea, 2018.

38. Ryu, Y. Ecology as image. In Criticism of International Competition for the Master Plan of Yongsan Park, Korea; Bom, Ed.; Namudosi: Goyang, Korea, 2013.

39. Editorial board of Environment \& Landscape Architecture of Korea. Special issue: Ten spaces and five perspectives. Environ. Landsc. Archit. Korea 2005, 201, 50-163.

40. Han, B. New development and half success. In Parkscape; Editorial board of Environment \& Landscape Architecture of Korea, Ed.; Jogyeong: Paju, Korea, 2006; pp. 302-305.

41. Lee, K. Sustaining its status and management of ecological park. Environ. Landsc. Archit. Korea 1993, 61, 54-59.

42. Haddad, L. Happening: Paradigms of light aBlaze (a dialectic of the sublime and the picturesque). Landsc. J. 1996, 15, 48-57. [CrossRef]

43. Meyer, E.K. Seized by sublime sentiments: Between terra firma and terra incognita. In Richard Haag: Bloedel Reserve and Gas Works Park; Saunders, W.S., Ed.; Princeton Architectural Press: New York, NY, USA, 1998; pp. 5-28.

44. ASLA (American Society of Landscape Architects). 2004. ASLA 2004 Professional Awards: Seonyudo Park, Seoul, South Korea. Available online: https:/ / www.asla.org/awards/2004/04winners/entry557.html/ (accessed on 25 July 2021).

45. Pae, J. Beyond Landscape Architecture; Jogyeong: Paju, Korea, 2007.

46. Jeong, W.; Corner, J. Fresh Kills park design, Staten Island, New York. J. Korean Inst. Landsc. Archit. 2005, 33, 93-108.

47. Pae, J. A 'new landscape' in Downsview Park international design competition. Environ. Landsc. Archit. Korea 2001, 153, 68-75.

48. Ahn, G. The plan of the Seoul Forest. Environ. Landsc. Archit. Korea 2005, 209, 50-53.

49. Chin, Y. Prairie hanging in the sky: Spatial metaphor of Nanji Sky windflowers park. Environ. Landsc. Archit. Korea 2000, 150, 92-97.

50. SeoAhn. The Seonyudo Park design competition. Environ. Landsc. Archit. Korea 2000, 143, 38-39.

51. Pae, J. Theory and critical practice in contemporary landscape design (8): An emerging field of the landscape urbanism. Environ. Landsc. Archit. Korea 2001, 164, 90-95.

52. Czerniak, J.; Hargreaves, G. (Eds.) Large Parks; Pae, J.; IDLA, Translators; Jogyeong: Paju, Korea, 2010.

53. Lee, M.; Pae, J. Landscape Urbanism as 're-distribution of the sensible'. In Landscapes in Flux, Proceedings of the European Council of Landscape Architecture Schools Conference, Tartu, Estonia, 20-23 September 2015; Niin, G., Sekhar Mishra, H., Eds.; Eesti Maaülikool: Tartu, Estonia, 2015; pp. 177-179.

54. Mostafavi, M.; Doherty, G. (Eds.) Ecological Urbanism; Lars Muller: Zurich, Switzerland, 2010.

55. Burley, J.B. The emergence of Landscape Urbanism. Land 2018, 7, 147. [CrossRef]

56. Editorial board of Landscape Architecture Korea. Collection of International Competition for Master Plan of the Yongsan Park; Landscape Architecture Korea: Paju, Korea, 2013.

57. PARKKIM. Available online: https:/ / parkkim.net/ (accessed on 25 July 2021). 
58. Czerniak, J. Legibility and resilience. In Large Parks; Czerniak, J., Hargreaves, G., Eds.; Princeton Architectural Press: New York, NY, USA, 2007; pp. 215-251.

59. Choi, H.; Seo, Y. The process of creating Yongsan Park from the urban resilience perspective. Sustainability 2019, $11,1225$. [CrossRef]

60. Choi, H.; Seo, Y. Design strategies and processes through the concept of resilience. J. Korean Inst. Landsc. Archit. 2018, 46, 44-58. [CrossRef]

61. Park, Y.; Kim, J. Alternative Nature; Mediabus: Seoul, Korea, 2016.

62. Walliss, J.; Rahmann, H. Landscape Architecture and Digital Technologies: Re-Conceptualising Design and Making; Routledge: London, $\mathrm{UK}, 2016$.

63. Kim, A.; Kim, Y.; Lee, J.; Lee, K.; Lee, M.; Lee, Y.; Na, S.; Pae, J.; Ryu, Y.; Seong, J.; et al. New Field of Korean Landscape Architecture; Hansoop: Seoul, Korea, 2021.

64. Seoul Metropolitan Government. Available online: http:/ / english.seoul.go.kr/seouls-new-gwanghwamun-to-return-to-thecitizens-in-2021/ (accessed on 7 August 2021).

65. Na, S. Case analysis and applicability review of parametric design in landscape architectural design. J. Korean Inst. Landsc. Archit. 2021, 49, 1-16. [CrossRef]

66. Jeon, S.; Lee, Y. Use of environmental analysis algorithm in landscape design. In Proceedings of the Fall Academic Conference of the Korean Institute of Landscape Architecture, Seoul, Korea, 15 October 2021; pp. 57-58.

67. Han, Y.; Kim, Y. Thermal comfort analysis of landscape design using ENVI-met: Case of Gwanghwamun Square design. In Proceedings of the Fall Academic Conference of the Korean Institute of Landscape Architecture, Seoul, Korea, 15 October 2021; pp. 55-56.

68. ArchDaily, SEOULLO Skygarden, MVRDV. Available online: https://www.archdaily.com/882382/seoullo-skygarden-mvrdv (accessed on 23 August 2021).

69. Kim, M. New Gwanghwamun Square. Landsc. Archit. Korea 2019, 371, 14-19. 